\title{
The Use of Biotechnology for Biodegradation of Paper Manufacturing Wastes (Kraft Lignin) Via Egyptian Bacterial Isolates
}

\author{
Abuo Gabal A. ashgan ${ }^{1}$; Abd Elsalam E. Hassan ${ }^{2}$ Abd Al-Aziz A. Samia ${ }^{3}$; El-Hanafy A. Amr ${ }^{3}$; \\ and Mohamed E. Abdallah. ${ }^{2}$
}

\begin{abstract}
Lignin contained in pulping liquor that is generated during the pulping process for papermaking is a disposal problem for the pulp and paper industry because it causes a serious pollution and toxicity problem in aquatic ecosystems, owing to its low biodegradability and high range of color. Four bacterial strains were isolated from soil, water and activated sludge samples which were collected from the effluent treatment plant of Rakta Pulp and Paper Company, Eltabia, Alexandria, Egypt in sterile test tubes. After isolation and purification of the bacterial isolates, they were tested for the degradation of kraft lignin (KL) using sterile mineral salt medium (MSM) containing KL $1000 \mathrm{mg} \mathrm{l}^{-1}$ (designated hereafter L-MSM) and supplemented with $1.0 \%$ glucose and $0.5 \%$ peptone (w/v) added in L-MSM-broth and L-MSM-agar as growth supportive substrates and incubated for seven days under aerobic conditions at $30{ }^{\circ} \mathrm{C}$ and $120 \mathrm{rpm}$. Samples were withdrawn periodically at 1-day intervals for seven days and analysed for bacterium growth, reduction of color and residual KL content. The isolates were subjected to $16 \mathrm{~S}$ rDNA sequence for identification. Partial sequence of $16 \mathrm{~S}$ rDNA revealed that these isolates were Bacillus subtilis subsp. Subtilis, Citrobacter farmeri, Escherichia fergusonii and Stenotrophomonas rhizophila. The average reduction of color was 85.4, 70.1, 61.7 and $74.5 \%$ and lignin degradation 71.4, 62.2, 54.5 and $57.1 \%$, respectively.
\end{abstract}

Key words: Biotechnology, Biodegradation, kraft lignin, 16S rDNA and bacteria

\section{INTRODUCTION}

Environmental pollution has been increased by increasing the industry development all over the world and especially in Egypt; increment of these pollution caused many hazards for all organisms, even for human such as carcinogenicity and toxicity. Also there has been increased pollution with hydrocarbon compounds. Many of these hydrocarbons considered to be a potential health hazard (Hassan et al., 2009). Historically, pulp and paper production has been recognized as a significant point source of pollution (Sun et al., 2004). It is the sixth largest polluter (after the oil, cement, leather, textile and steel industries), discharging a variety of gaseous, liquid and solid wastes into the environment which can cause considerable damage to the receiving waters if discharged untreated (Ali and Sreekrishnan, 2001) and (Gürs Es et al., 2002). They block the passage of light to the lower depths of the aquatic system resulting in cessation of photosynthesis, leading to anaerobic conditions, which in turn result in the death of aquatic life causing foul smelling toxic waters (Chandralata et al., 2008).

In order to manufacture good quality paper, the pulp and paper industry discards lignin as an unwanted constituent of wood and raw materials and therefore discharges a significant amount of effluent or wastewater containing lignin and other hazardous materials. Black liquor is one of the main byproducts discarded as waste which has a high level of chemical oxygen demand (COD) and contains lignin from 10 to $50 \%$ by weight (Ksibi et al., 2003). If is not removed from the treated wastewater, the lignin presents a serious pollution and toxicity problem in aquatic ecosystems, owing to its low biodegradability and high range of color.

For several decades, a number of methods for black liquor treatment have been developed, e.g., adsorption of organic pollutants from kraft pulp mill wastewater using activation carbon and polymer resin and chemical coagulation of lignin from pulp and paper wastewater using synthetic and natural coagulants. However, these processes are not very effective, but are costly. Furthermore, in these processes lignin compounds are not degraded, but are just transferred from a watersoluble state into a solid state. Biological treatment is found to be more efficient, less costly than previous mentioned methods and has no hazard impact on the ambient environment. In biological treatment systems a wide variety of microorganisms including fungi,

\footnotetext{
${ }^{1}$ Faculty of Agriculture - Saba Basha, Genetic Department, Alexandria University, Egypt.

${ }^{2}$ Arid lands Cultivation and Development Research Institute, Soil and water Technologies Department, City for Scientific Research and Technology Applications, Egypt.

${ }^{3}$ Genetic Engineering and Biotechnology Research Institute, Nucleic Acids Research Department,

City for Scientific Research and Technology Applications, Egypt.

Corresponding Author: Ashgan E. Abou Gabal, E-mail:

ashgabal@yahoo.com, zamhelsayed@yahoo.com

Received November 13, 2011, Accepted November 28, 2011
} 
actinomycetes and unicellular bacteria have been implicated in lignin biodegradation and decolourization of pulping effluent (Yang et al., 2007).

Bacteria, in particular, deserve to be studied for ligninolytic potential because of their immense environmental adaptability and biochemical versatility. In addition the application of fungi in bioleaching of raw pulp is not feasible due to its structure hindrance caused by fungal filament .Several studies have investigated biological treatment of black liquor by using various pure bacterial strains.(Chandra et al., 2007).

Increased knowledge about the environmental effects of industrial activities has led to a need for developing better techniques and more efficient waste management systems in order to reduce their environmental impact (Tiina et al., 2009). Therefore, the main objective of this study was to overcome the problems of contamination of water with paper manufacturing wastes (black liquor) using genetical and biotechnological methods.

\section{MATERIALS AND METHODS}

\section{1- Samples collection:}

Soil, water and activated sludge samples were collected from the effluent treatment plant of Rakta Pulp and Paper Company, Eltabia, Alexandria, Egypt in sterile test tubes. The industry uses the kraft process for pulping of raw materials, mainly rice straw. Subsequently this pulp is bleached by multistage chlorination. The effluent generated by this process contain high concentrations of dissolved kraft Lignin (KL), chlorophenol and other soluble components of the raw material, which subsequently undergo activated sludge treatment after filtration of residual wood fibers. The sludge of the treatment plant remains rich with ligninolytic bacteria. Hence, water, soil and the activated sludge samples were collected for the isolation of potential ligninolytic bacteria.

\section{2- Media composition, bacterial isolation and screening:}

All chemicals used in this study were obtained from Sigma and Fisher Companies. Alkali Kraft Lignin (KL) degrading bacteria was isolated from water, soil and the effluent sludge by enrichment culture technique (Morii et al., 1995). $5 \mathrm{ml}$ of sludge, $5 \mathrm{ml}$ of contaminated water and $5 \mathrm{gm}$ of soil sample separately were inoculated to $100 \mathrm{ml}$ sterile mineral salt medium (MSM) containing $\mathrm{KL} 500 \mathrm{mg} \mathrm{l}^{-1}$ (designated hereafter L-MSM). MSM ( $\mathrm{pH}$ 7.6) consisted of ( $\mathrm{g} \mathrm{l}^{-1}$ de-ionized water): $\mathrm{Na}_{2} \mathrm{HPO}_{4}$, $2.4 ; \mathrm{K}_{2} \mathrm{HPO}_{4}, 2.0 ; \mathrm{NH}_{4} \mathrm{NO}_{3}, 0.1 ; \mathrm{MgSO}_{4}, 0.01 ; \mathrm{CaCl}_{2}$, 0.01 and Trace elements solution $1.0 \mathrm{ml}$. The latter solution composed of $(\mathrm{mg} / \mathrm{l}): \mathrm{ZnCl}_{2}, 70 ; \mathrm{MnCl}_{2} \cdot 4 \mathrm{H}_{2} \mathrm{O}$, 100; $\mathrm{CoCl}_{2} \cdot 6 \mathrm{H}_{2} \mathrm{O}, 50 ; \mathrm{NiCl}_{2} .6 \mathrm{H}_{2} \mathrm{O}, 50 ; \mathrm{CuCl}_{2} \cdot 2 \mathrm{H}_{2} \mathrm{O}, 25$;
$\mathrm{NaMoO}_{4} \cdot 2 \mathrm{H}_{2} \mathrm{O}, 50 ; \mathrm{NaSeO}_{3} .5 \mathrm{H}_{2} \mathrm{O}, 26 ; \mathrm{NaVO}_{3} \cdot \mathrm{H}_{2} \mathrm{O}, 10$; $\mathrm{NaWO}_{4} \cdot 2 \mathrm{H}_{2} \mathrm{O}, 30$ and $\mathrm{HCl} 25 \%, 1.0 \mathrm{ml}$.

The bacterial strains could not grow using $\mathrm{KL}$ as a single carbon source due to its high molecular weight. Therefore, through nutrient optimization process, $1.0 \%$ glucose and $0.5 \%$ peptone (w/v) were added in L-MSMbroth and L-MSM-agar as growth supportive substrates. Flasks were incubated for 6 days on rotary shaker 120 rpm under aerobic conditions at $30{ }^{\circ} \mathrm{C}$. Samples from flasks exhibiting decolourisation were serially diluted and spread on L-MSM agar plates and incubated in dark at $30^{\circ} \mathrm{C}$ for 6 days. Four phenotypically different bacterial colonies were picked and purified by repeated sub-culture in order to obtain pure isolates. The purity of isolates was checked by microscope and these isolates were designated 1, 2, 3 and 4 .

\section{3- Bacterial isolates identification:}

\subsection{1- DNA extraction and purification:}

Extraction and purification of total genomic DNA was carried out according to Leonard et al., 1986. Four isolates were routinely cultured at $30^{\circ} \mathrm{C}$ on luria-Bertani (LB) medium. Bacterial cultures for DNA extraction were grown in broth at $30^{\circ} \mathrm{C}$.Total bacterial genomic DNA was extracted as follows: five $\mathrm{ml}$ of overnight cultured bacterial cells were centrifuged for 10 minutes at $10000 \mathrm{rpm}$ (High-speed centrifuge sorvall RC 285, USA) subsequently, the resulted pellets were resuspended in $467 \mu \mathrm{l}$ lyses buffer containing: $30 \mu \mathrm{l}$ of $10 \%$ sodium dodicyl sulphate (SDS) and $3 \mu$ proteinase $\mathrm{K}(20 \mathrm{mg} / \mathrm{ml})$, mixed well and incubated for one hour at $37{ }^{\circ} \mathrm{C}$. The protein/DNA mixture was then subjected to phenol/chloroform extraction, and the upper aqueous phase was transferred to a new tube .Directly, for DNA precipitation an equal volume of absolute ethanol and $1 / 10$ volume sodium acetate (pH5.2) were added and incubated at $-20{ }^{\circ} \mathrm{C}$ at least one hour .After centrifugation, the resulted pellets of DNA were washed twice with $70 \%$ ethanol then air dried, dissolved in $20 \mu \mathrm{l}$ sterile distilled water, and stored at $-20{ }^{\circ} \mathrm{C}$ until used.

\subsection{2- Sequence analysis of $16 S \mathrm{r}$ DNA genes:}

Though the 16S rRNA gene is found conserved on evolutionary scale, it is still diverse enough to identify and classify the eubacteria (Amman et al., 1995). 16S rRNA gene sequencing involves amplification of target sequences using universal primers to yield a $1.5 \mathrm{~kb}$ amplicon followed by sequencing and homology generation using ribosomal DNA database.

The 16S rRNA gene was amplified using universal eubacterial primers (Narde et al., 2004). Polymerase chain reaction (PCR) reaction was performed using (eppendorff 9700 thermocycler) under the following conditions: Initial denaturation at $94{ }^{\circ} \mathrm{C}(5 \mathrm{~min}), 35$ 
cycles of denaturation at $94{ }^{\circ} \mathrm{C}(1 \mathrm{~min})$, annealing at 57 ${ }^{\circ} \mathrm{C}(1 \mathrm{~min})$, extension at $72{ }^{\circ} \mathrm{C}(2 \mathrm{~min})$, final extension at $72{ }^{\circ} \mathrm{C}(10 \mathrm{~min})$ and stored at $4{ }^{\circ} \mathrm{C}$. Product was amplified using the universal primer (forward primer 5 AGAGT TTGATCMTGGCTCAG- $3^{\prime}$ and reverse primer 5'-TACGGYTACCTTG TTACGACTT-3').

\section{Reaction preparation:}

For each reaction the following reagents were added to a separate $0.2 \mathrm{ml}$ PCR tube: $5 \mu$ l buffer $10 \mathrm{x}, 1 \mu \mathrm{l}$ Template DNA, $2 \mu 1$ of forward \& reverse universal Primers, $5 \mu \mathrm{l}$ dNTPs, $0.4 \mu \mathrm{l}$ (5units/ $\mu \mathrm{l}$ ) Taq Polymerase (Sigma), De-ionized water was added up to a total volume $50 \mu \mathrm{l}$, then, the mixture was mixed well.

\subsection{3- Electrophoresis of the sequencing reaction:}

Two $\mu l$ of loading dye were added prior to loading of $10 \mu \mathrm{l}$ per well. Electrophoresis was performed at 80 volt (mini-sub DNA electrophoresis gel 170-4307 and power supply 1000/500 from Bio-Rad, USA) with 1x tris boric acid EDTA(TBE) buffer in $1.5 \%$ agarose gels and then the gel was stained in $0.5 \mu \mathrm{g} / \mathrm{ml}(\mathrm{w} / \mathrm{v})$ ethidium bromide solution and destained in deionized water. Finally the gel was visualized and photographed by using gel documentation system (Alpha Imager TM1220, Canada). Size of the target band was estimated using DNA marker (100 base-pair ladder).

\subsection{4- Sequencing alignments and phylogenetic analysis:}

Sequencing steps were performed at Gene Analysis unit, VACSERA. Cycle sequencing was done by using a Bigdye terminator cycle sequencing kit (Applied Biosystems, Foster City). Sequencing products were purified by using Centri-sep spin Column and were resolved on an applied Biosystems Model 310 automated genetic analyzer. Approximately $1500 \mathrm{bp}$ was sequenced and phylogenetic and molecular evolutionary analyses of the lignin degrading bacteria based on $16 \mathrm{~S}$ rDNA gene were conducted using software MEGA ver. 4 (Tamura et al., 2007).

\section{4- Kraft Lignin de-colourisation and degradation:}

Biodegradation experiment was carried out in 100 $\mathrm{ml}$ flask containing $50 \mathrm{ml}$ sterile L-MSM (1000 $\mathrm{mg} \mathrm{l}^{-1}$ $\mathrm{KL})$ at $\mathrm{pH} 7.6$, which is greater than that found in pulp mill effluent. Culture suspension $1 \%(\mathrm{v} / \mathrm{v})$ having an inoculum size $(\mathrm{CFU}) / \mathrm{ml} 105 * 10^{4}$ was inoculated into triplicate flasks. The inoculum was grown overnight in 100-ml flasks containing $50 \mathrm{ml}$ luria-Bertani (LB) broth. The flasks were incubated for seven days on rotary shaker incubator under aerobic conditions at $30^{\circ} \mathrm{C}$ and $120 \mathrm{rpm}$. Uninoculated medium was used as control in all cases. Samples were withdrawn periodically at 1-day intervals for seven days and analysed for bacterium growth, reduction of colour and residual KL content.

\section{Analytical techniques:}

\subsection{1- Bacterium growth:}

Cell growth was determined by measuring absorbance of inoculated sample at $620 \mathrm{~nm}\left(\mathrm{~A}_{620}\right)$ on spectrophotometer (UV-visible Cintra 40-GBC) using uninoculated medium as blank.

\subsection{2- Colour reduction:}

The colour reduction of the effluent was determined according to (Morii et al., 1995). For the measurement of color, samples were centrifuged at $8000 \mathrm{~g}$ for $30 \mathrm{~min}$ (High-speed centrifuge, sorvall RC 285, USA) to remove the biomass. Supernatant $(1 \mathrm{ml})$ was diluted by adding $3 \mathrm{ml}$ phosphate buffer ( $\mathrm{pH}$ 7.6) and absorbance measured at $465 \mathrm{~nm}$ for colour reduction. The absorbance at $465 \mathrm{~nm}$ against distilled water was measured using a spectrophotometer (Shimadzu, UV2200). The absorbance values were then transformed into colour units (CU) according to the following formula.

$\mathrm{CU}=500 \times(\mathrm{A} 2 / \mathrm{A} 1)$

Where A1 corresponds to the A465 of a 500-CU platinumcobalt standard solution; and A2 is the absorbance of the effluent sample. The color removal (\%) was defined as the ratio of $\mathrm{CU}$ of the culture supernatant to that of the initial medium.

Colour removal $\%=(\mathrm{A}-\mathrm{B}) \backslash \mathrm{A} \times 100$

Where $\mathrm{A}$ is colour units of uninoculated sample and $B$ is colour units of inoculated sample.

\subsection{3- Lignin content:}

For the estimation of residual lignin, centrifuged supernatants from control and inoculated were acidified with $12 \mathrm{M} \mathrm{HCl}$ to $\mathrm{pH} 1-2$ and then centrifuged at $12,000 \mathrm{~g}$ for $10 \mathrm{~min}$. Residual KL was obtained after each precipitate had been washed with de-ionised water and dried at $60{ }^{\circ} \mathrm{C}$ for $48 \mathrm{~h}$ and weighed (Anthony et al., 1986). Kraft lignin loss (\%) in the supernatants decolourised by the strain was determined daily for seven days as dry weight (estimating $100 \%$ as the KL present in the same volume of uninoculated medium). All experiments were carried out in triplicates. The values are presented as mean \pm standard deviation $(n=$ $3)$.

\section{RESULTS AND DISCUSSION}

\section{1- Bacterial isolation and screening:}

In order to obtain the largest possible collection of lignin-degrading bacteria soil, water and pulp paper sludge were added directly to L-MSM as the source of ligninolytic bacteria with the medium containing glucose and peptone as additional carbon and nitrogen sources to stimulate bacterial growth and hence the decolourization of KL was observed. Vicuna (1988) also 
reported that, as glucose and nitrogen were essential as co-substrate in media to promote bacterial growth for degradation of lignin. After incubation for 7 days when samples in flasks showed visible decolourization were plated on L-MSM agar, four bacterial isolates were selected for detail characterisation and biodegradation assay on the basis of their growth on tested lignin concentration (1000 $\mathrm{mg} \mathrm{l}^{-1}$ ), colour reduction and lignin degradation.

\section{2- Bacterial isolates identification:}

3.2.1- Sequencing alignments and phylogenetic analysis:

Table 1. Similarity percentage of $16 \mathrm{~S}$ rDNA sequences for the selected isolates to those obtained from database

\begin{tabular}{llcc}
\hline Isolate & Organism & Identity (\%) & Accession NO. \\
\hline \multirow{2}{*}{ Bacillus subtilis subsp. } & Bacillus subtilis subsp. subtilis strain DSM 10 & 98 & NR027552 \\
Subtilis & Bacillus vallismortis strain DSM11031 & 98 & NR024696 \\
\hline \multirow{2}{*}{ Citrobacter farmeri } & Citrobacter farmeri strain CDC 2991-81 & 98 & NR024861 \\
& Salmonella enterica subsp. indica & 97 & NR044370 \\
\hline \multirow{2}{*}{ Escherichia fergusonii } & Escherichia fergusonii ATCC 35469 & 94 & NR027549 \\
& Escherichia albertii strain Albert 19982 & 94 & NR025569 \\
\hline \multirow{2}{*}{ Stenotrophomonas rhizophila } & Stenotrophomonas rhizophila strain e-p10 & 86 & NR028930 \\
& Xanthomonas oryzae strain LMG 5047 & 87 & NR026319 \\
\hline
\end{tabular}

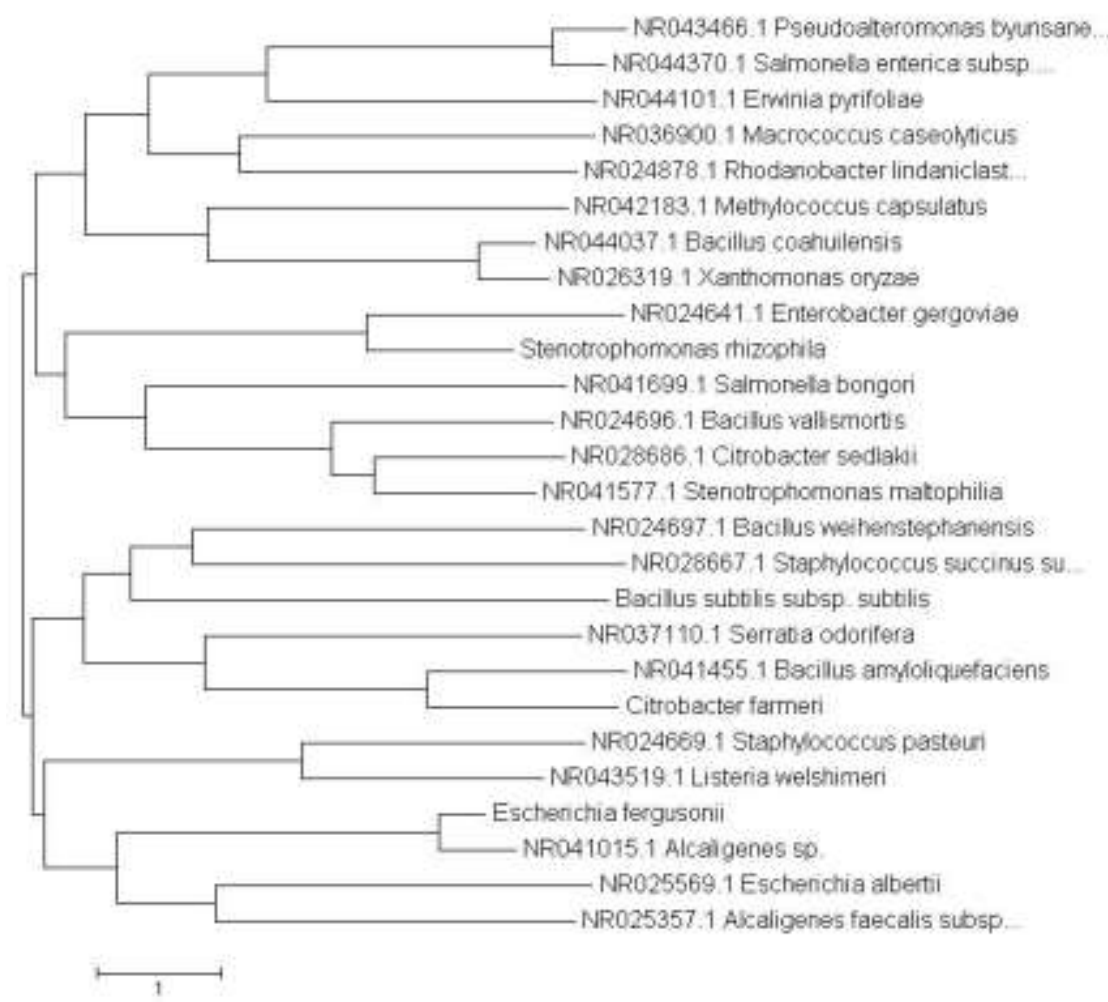

Fig. 1. Phylogenetic tree of Bacillus subtilis subsp. Subtilis, Citrobacter farmeri, Escherichia fergusonii, and Stenotrophomonas rhizophila strains and their related genera have been linked based on partial 16S rDNA sequence comparisons 
The phylogeny of the bacterial strains and closely related species was analysed using the multi-sequence alignment program and the results are presented in Fig. 1. The phylogenetic tree displayed that the four strains were grouped in two clusters, the first cluster is divided into two sub-clusters one of them includes strain Stenotrophomonas rhizophila. The other cluster includes the remaining three strains and divided into two sub clusters, one of these sub clusters contain two strains, Bacillus subtilis subsp. Subtilis and Citrobacter farmeri. The remained strain Escherichia fergusonii was found in the other sub cluster.

\section{3- Kraft Lignin de-colourization and degradation:}

When the decolourization assay was carried out in (L-MSM), pH 7.6 in shaked flasks at $30{ }^{\circ} \mathrm{C}$, a marked increase in optical density (OD) growth at $620 \mathrm{~nm}$ revealed that growth reached maximum at $4^{\text {th }} \mathrm{d}$ for the four isolates and thereafter declined (Fig. 2). However there was less reduction of colour, lignin and total substrate present in the culture media of flask at initial $48 \mathrm{~h}$ incubation as shown in Figs. 3 and 4, possibly because bacteria initially utilized glucose for growth and subsequently utilized lignin as a co-metabolite (Jeffries et al., 1981) after that, there were greater colour and lignin reduction (Figs. 3 and 4). The colour reduction and lignin degradation reached a maximum by $5^{\text {th }}$ day for Bacillus subtilis subsp. Subtilis $(85.4 \%, 71.4 \%)$, and Citrobacter farmeri $(74.5 \%, 62.2 \%)$ and by $6^{\text {th }}$ day for Escherichia fergusonii (61.7\%, 54.5\%), and Stenotrophomonas rhizophila (70.1\%, 57.1\%), respectively. The reduction of colour resulting from lignin biodegradation has been assumed to be due to depolymerisation of lignin polymers by bacterial ligninolytic systems (Perestelo et al., 1989).

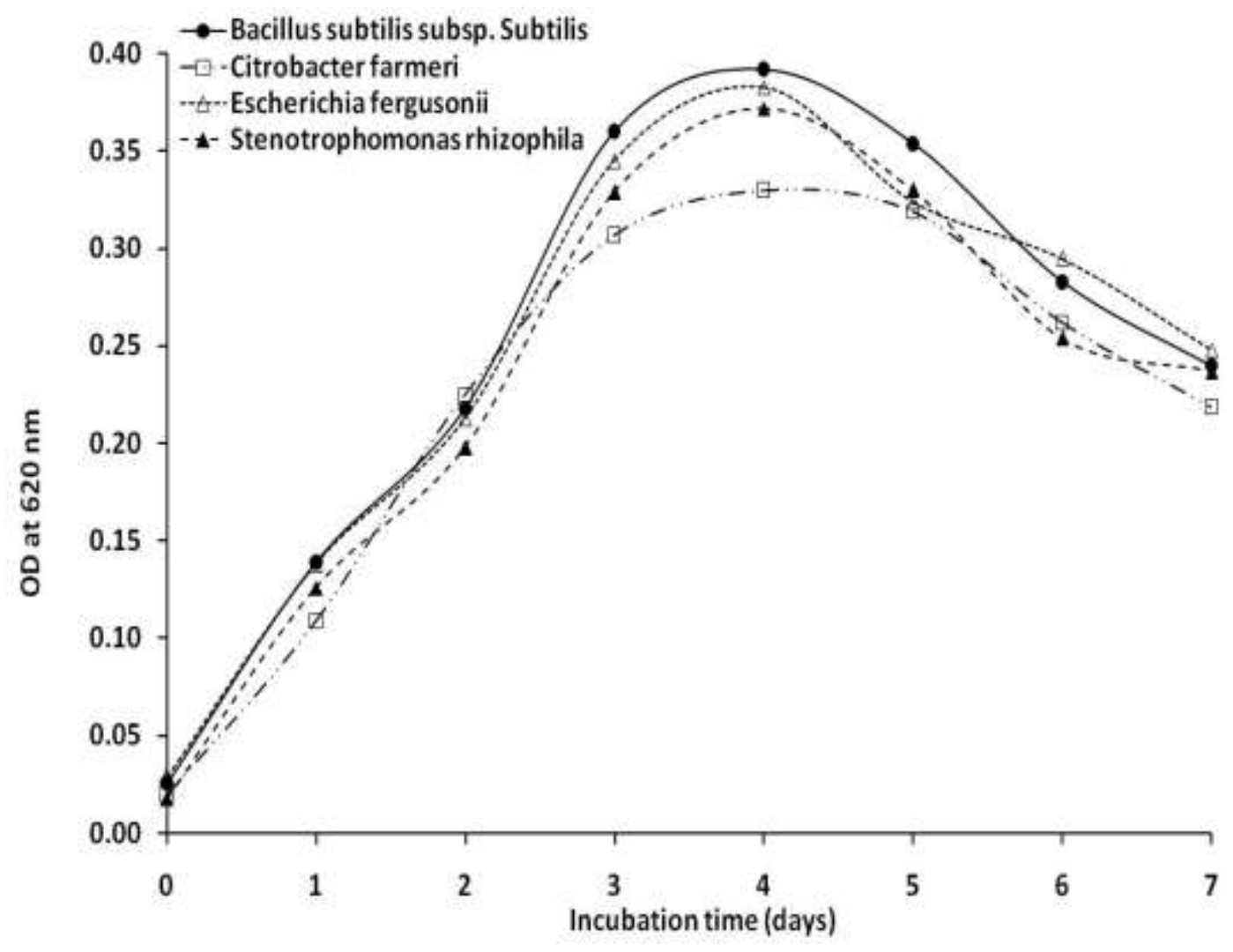

Fig. 2. The relation between incubation time (days) and the growth (optical density) of Bacillus subtilis subsp. Subtilis, Citrobacter farmeri, Escherichia fergusonii, and Stenotrophomonas rhizophila strains 


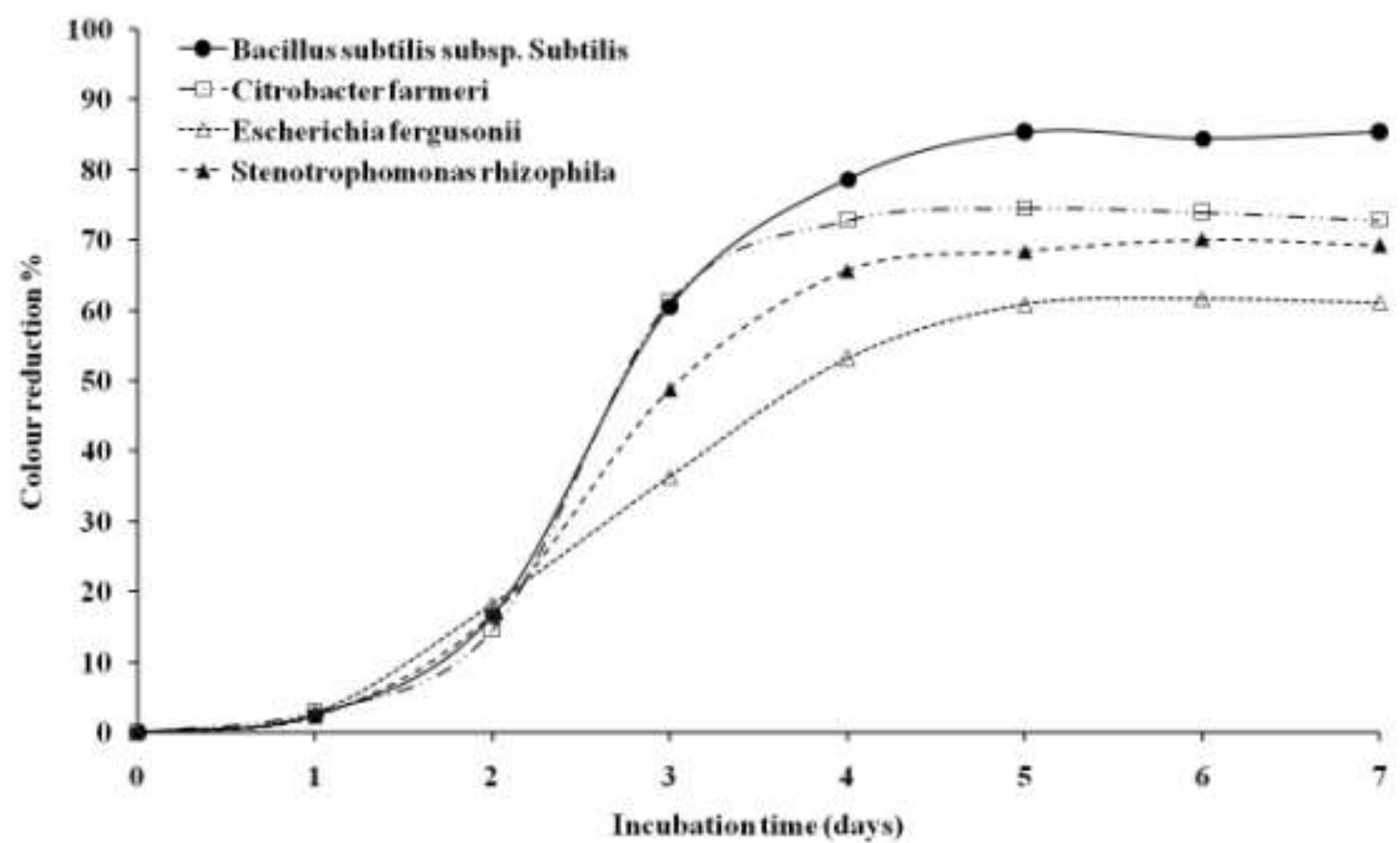

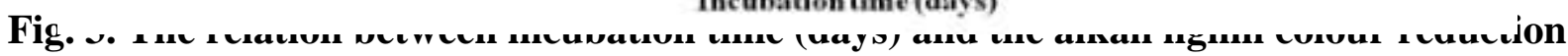

(\%) of Bacillus subtilis subsp. Subtilis, Citrobacter farmeri, Escherichia fergusonii, and Stenotrophomonas rhizophila strains

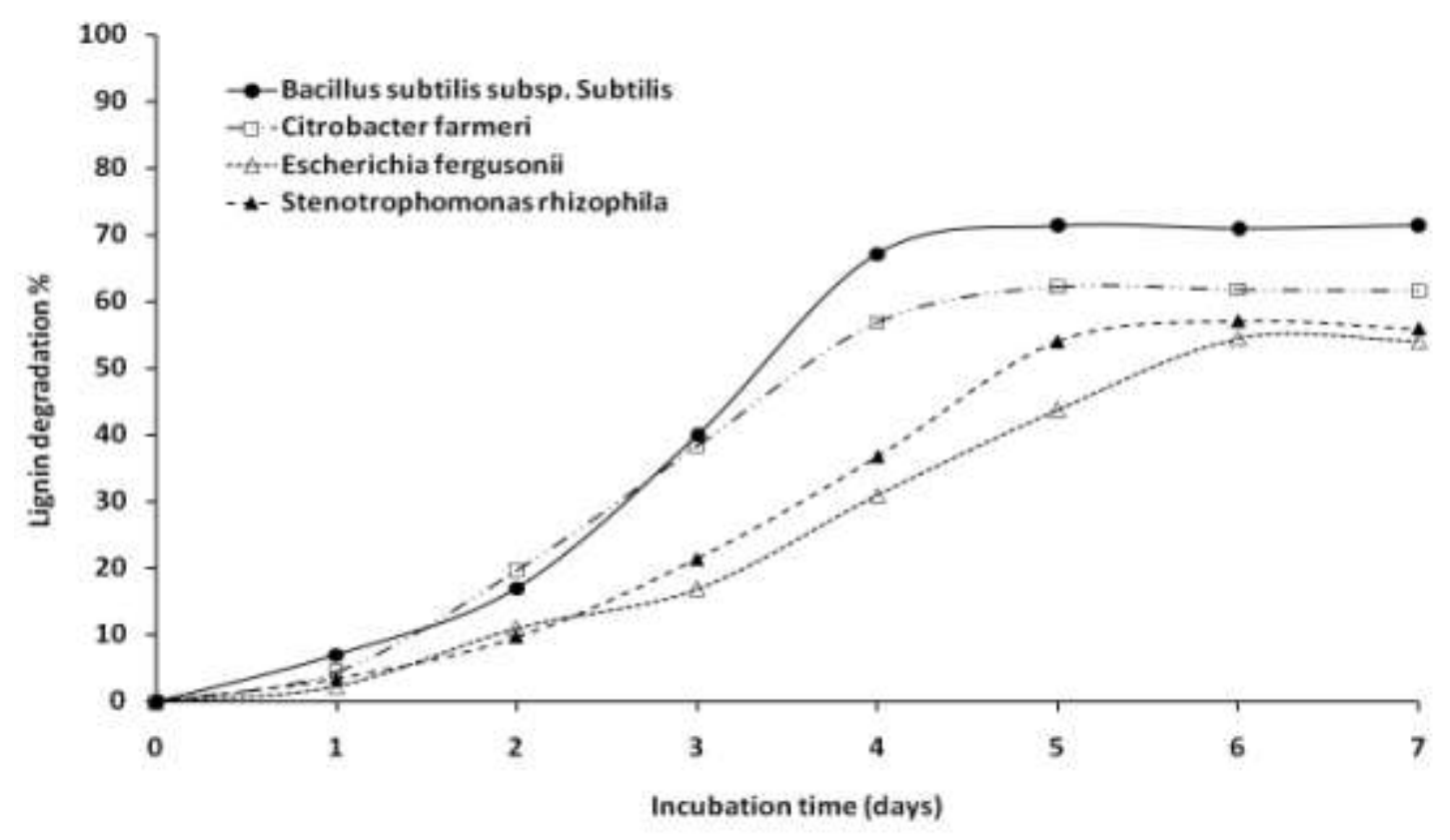

Fig. 4. The relation between incubation time (days) and the alkali lignin degradation rate (\%) of Bacillus subtilis subsp. Subtilis, Citrobacter farmeri, Escherichia fergusonii, and Stenotrophomonas rhizophila strains 


\section{ACKNOWLEDGEMENTS}

This work was supported by a grant from the Academy of Scientific Research \& Technology (ASRT), Egypt. Genetic Engineering and Biotechnology Research Institute (GEBRI), Environmental Biotechnology Department and nucleic Acids Department, City for Scientific Research and Technology Applications, Egypt.

\section{REFERENCES}

Ali, M. and Sreekrishnan, T.R., 2001. Aquatic toxicity from pulp and paper mill effluents: A review. Adv. Environ. Res. 5, 175-196.

Amann, R.A., Ludwig, W., Schleifer, K.H., 1995. Phylogenetic identification and in situ detection of individual microbial cells without cultivation. Microbiol. Rev. 59, 143-169.

Anthony L., Pomitto A. and Crawford D., 1986. Effect of pH on lignin and cellulose degradation by Streptomyces viridosporus. Appl Environ Microbiol 52:246-250.

Chandra R., Raj A., Purohit H J. and Kapley A., 2007. Characterization and optimization of three potential aerobic bacterial strains for kraft lignin degradation from pulp paper waste. Chemosphere. 67 (4): 839-846.

Chandralata Raghukumar, Donna D'Souza -Ticlo and Ashutosh Kumar Verma, 2008. Treatment of colored effluents with lignin-degrading enzymes: An emerging role of marine-derived fungi. Critical Reviews in Microbiology, vol.34; 189-206.

Gürs Es A., Yal Çin M. and Doğar Ç., 2002. Electrocoagulation of some reactive dyes: a statistical investigation of some electrochemical variables, Waste Management. 22, 491.

Hassan E. Abd-Elsalam, Elsayed E. Hafez, Azhar A. Hussain, Amany G. Ali and Amr A. El-Hanafy, 2009. Isolation and Identification of Three Rings Polyaromatic Hydrocarbons (Anthracene and Phenanthrene) Degrading Bacteria. American-Eurasian J. Agric. \& Environ. Sci., 5 (1): 31-38.
Jeffries, T.W., Choi, S., Kirk, T.K., 1981. Nutritional regulation of lignin degradation by Phanerochaete chrysosporium. Appl. Environ. Microbiol. 42, 290-296.

Ksibi M., Amor S.B., Cherif S., Elaloui E., Houas A., Elaloui M., 2003. Photodegradation of lignin from black liquor using a UV/TiO2 system, J. Photochem. Photobiol. A: Chem. 154, 211.

Leonard, G.,z Mark, D., and James, F., 1986. Basic Methods in Molecular Biology. Elsevier. Co. Inc. Avenue, New York. USA.

Morii, H., Nakamiya, K., Kinoshita, S., 1995. Isolation of lignin decoloursing bacterium. J. Ferment. Bioeng. 80, 296-299.

Narde, G., Kapley, A., Purohit, H.J., 2004. Isolation and characterization of Citrobacter strain HPC 255 for broad range substrate specificity for chlorophenol. Curr. Microbiol. 48, 419-423.

Perestelo, F., Falcon, M. A., Prez, M. L., Riog, E. C., Martin, G. D., 1989. Bioalteration of kraft pine lignin by Bacillus megaterium isolated from compost piles. J. Ferment. Bioeng. 68, 151-153.

Sun, X. F., Sun, R. C., Tomkinson, J. and Baird, M. S., 2004. Degradation of wheat straw lignin and hemicellulosic polymers by a totally chlorine-free method. Polym. Degrad. Stab. 83, 47-57.

Tamura, K., J. Dudley, M. Nei and S. Kumar, 2007. MEGA4: Molecular Evolutionary Genetics Analysis (MEGA) software version 4.0. Molecular Biol. Evolution, 24: 1596-1599.

Tiina Leiviska, Jaakko Ramo, Hannu Nurmesniemi, Risto Poykio and Toivo Kuokkanen, 2009. Size fractionation of wood extractives, lignin and trace elements in pulp and paper mill wastewater before and after biological treatment. Water research. 43, 3199-3206.

Vicuna, R., 1988. Bacterial degradation of lignin. Enzyme Microbial. Technol. 10, 646-655.

Yang J S, Ni J R, Yuan H L and Wang E T, 2007. Biodegradation of three different wood chips by Pseudomonas sp. PKE117. International Biodeterioration \& Biodegradation. 60: 90-95. 


\section{الملخص العربي}

استخدام التكنولوجيا الحيوية فى التكسير الحيوى لمخلفات صناعة الورق (اللجنين) بواسطة عزلات

\section{بكتيرية مصرية}

$$
\text { أشجان ابوجبل, حسن عبدالسلام, سامية عبد الله، عمرو عبدالمعطى, عبدالله السيد مُحَّم }
$$

ومخلفات صناعة الورق من شركة راكتا لصناعة الورق بالاسكندرية

$$
\text { لعزل السلالات البكتيرية منها واجراء الدراسة عليها. }
$$

وتتلخص النتائج التى تم التوصل إليها فى هذا البحث في النقاط

$$
\text { التالية: }
$$

1 عزل أربع سلالات بكتيرية لما القدرة على تكسير اللجنين الموجود

$$
\text { في مخلفات صناعة الورق. }
$$

2 حـزل الحـامض النووى الديؤكسى ريبـوزى مـن السـلالات الأربعـة

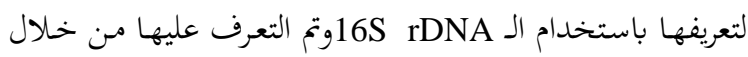

$$
\text { بنك الجينات على أهنا }
$$

Bacillus subtilis subsp. Subtilis, Citrobacter farmeri,

Escherichia fergusonii and Stenotrophomonas rhizophila.

3 تيم اختبـار قـدرة السـلالات الأربعة على تكسير اللجنـين وذلك

باختبـار قـدرةقا على النمـو ونسـبة اختزال لـون اللجنسين وكميـة

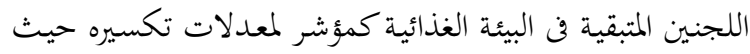

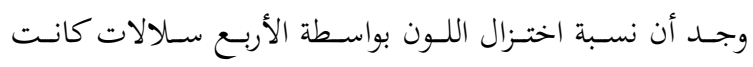

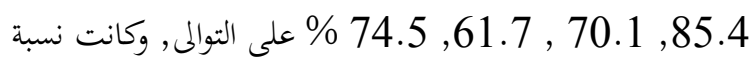

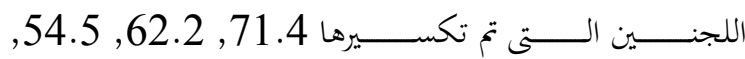

$$
57.1
$$

تعتبر مخلفات مصانع الورق من اكبر الملوثات البيئية لما تحتويه من

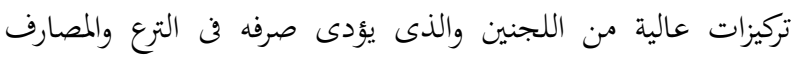

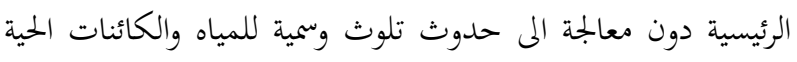
الموجودة في هذه المياه, وذلك لصعوبة تحلله. ومن هنا زاد الإهتمام بمعالجة هذه المخلفات, وكان يتم معالجتها من قبل باستخدام مواد

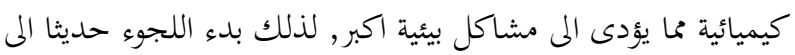

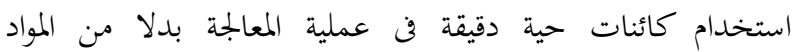
الكيميائية فهى اكثر كفاءة كما اها غير ضارة بالبيئة. ومن اهم هذه الكائنات الدقيقة هى البكتيريا لقدرتا على المعيشة فن بيئات متعددة وتحت ظروف مختلفة وقدرتا الاعلى على تكسير هذه المخلفات و ومعالجتها.

ويهدف البحث الحالى إلى استخدام الطرق الوراثية والتكنولوجيا الحيوية الحديثة لعزل وإستحداث سلالات بكتيرية لها قدرات متزايدة على تكسير المواد الضارة الناتجة عن التلوث بمخلفات مصانع الورق حيث تقوم هذه الكائنات الدقيقة بالتحطيم الحيوى للمركبات الهيدروكربونية طويلة السلسة والتى تعتبر من اهم الملوثات البيئة والتى يجب التخلص منها بطرق آمنة. وقد تم خلال هذه الدراسة جمع عينات من التربة والمياه 